\title{
ASO Author Reflections: Towards Fluorescence Guided Tumor Identification for Precision Breast Conserving Surgery
}

\author{
Maria Leiloglou, MSc ${ }^{1,2}$ (), Martha S. Kedrzycki, MSc, MRCS ${ }^{1,2,3}$, Daniel S. Elson, MSci, PhD ${ }^{1,2}$, and \\ Daniel R. Leff, FRCS, PhD, MS (Hons) ${ }^{1,2,3}$ \\ ${ }^{1}$ Hamlyn Centre, Institute of Global Health Innovation, Imperial College London, South Kensington Campus, London, UK; \\ ${ }^{2}$ Department of Surgery and Cancer, Imperial College London, London, $\mathrm{UK}^{3}$ Department of Breast Surgery, Charing Cross \\ Hospital, Imperial College Healthcare NHS Trust, London, UK
}

\section{PAST}

Breast conserving surgery (BCS) is the cornerstone surgical treatment in breast cancer; however, it is associated with a risk of reoperative intervention due to positive resection margins. ${ }^{1}$ Reoperation puts patients at risk of perioperative complications including infection and inferior cosmetic outcomes, as well as delays to adjuvant treatment. From the payor perspective, reoperation creates financial toxicity due to the direct costs of intervention as well as indirect costs due to time off work. Conventional localization techniques only provide approximate tumor location and fail to provide tumor identification or tissue characterization. ${ }^{1}$ Tumor identification through fluorescence guided surgery (FGS) is Food and Drug Administration approved for cancers such as glioblastoma where negative margins are paramount, ${ }^{2}$ and these benefits could be applied to BCS through demarcating tumor location, size, and invasiveness.

Maria Leiloglou and Martha S. Kedrzycki: Co-first authors.

(C) The Author(s) 2021

First Received: 19 July 2021

Accepted: 21 July 2021

Published Online: 18 August 2021

M. Leiloglou, MSc

e-mail: maria.leiloglou16@imperial.ac.uk

\section{PRESENT}

A prospective clinical trial was conducted using an inhouse fluorescence camera system in 40 patients undergoing BCS. Indocyanine green (ICG) at $0.25 \mathrm{mg} / \mathrm{kg}$ was administered to 20 patients at the start of the operation, and 20 patients intraoperatively, once skin flaps were raised. The patients who received an intraoperative ICG injection demonstrated a stronger tumor background ratio (TBR) than those who received preoperative ICG $(3.18 \pm 1.74$ vs $2.10 \pm 0.92, p=0.023$ ). However, sensitivity and specificity for the intraoperative cohort was not statistically different from that of the preoperative cohort $(0.82: 0.93 \mathrm{vs}$ 0.66:0.90 respectively, $p=1.105: p=0.909){ }^{3}$ The key finding of this study is relative improvement in TBR with intraoperative fluorescence injection. Whilst ICG provides a clinically adequate TBR $(>1.5),{ }^{3}$ further work is required to improve the diagnostic accuracy for the clinical adoption of fluorescence guided breast surgery.

\section{FUTURE}

Although when compared with previous specimen-based analysis, pixel-based image analysis was identified to be superior ${ }^{4,5}$ and high accuracy was attained, BCS using ICG requires appropriately powered clinical trials to determine whether patient outcomes are improved. Future work should also focus on improving results either through camera system modifications, enhancing image processing, and/or using targeted fluorophores specific to breast cancer towards clinical adoption of fluorescence guided breast surgery. 
FUNDING This paper is independent research funded by the National Institute for Health Research (NIHR) Imperial Biomedical Research Centre (BRC), the Cancer Research UK (CRUK) Imperial Centre, and the Imperial Confidence in Concept (ICiC) Joint Translational Fund (Imperial College's Medical Research Council [MRC] Confidence in Concept fund and the Engineering and Physical Sciences Research Council [EPSRC] Impact Acceleration Account scheme). The views expressed in this publication are those of the author(s) and not necessarily those of the NHS, the National Institute for Health Research or the Department of Health. Maria Leiloglou would like to acknowledge the support by the Greek Foundation for Education and European Culture (IPEP).

DISCLOSURES No conflict with any commercial interest.

OPEN ACCESS This article is licensed under a Creative Commons Attribution 4.0 International License, which permits use, sharing, adaptation, distribution and reproduction in any medium or format, as long as you give appropriate credit to the original author(s) and the source, provide a link to the Creative Commons licence, and indicate if changes were made. The images or other third party material in this article are included in the article's Creative Commons licence, unless indicated otherwise in a credit line to the material. If material is not included in the article's Creative Commons licence and your intended use is not permitted by statutory regulation or exceeds the permitted use, you will need to obtain permission directly from the copyright holder. To view a copy of this licence, visit http://creativecommons. org/licenses/by/4.0/.

\section{REFERENCES}

1. Ananthakrishnan P, Balci FL, Crowe JP. Optimizing surgical margins in breast conservation. Int $J$ Surg Oncol. 2012;2012:e585670. https://doi.org/10.1155/2012/585670.

2. Eljamel S. 5-ALA fluorescence image guided resection of glioblastoma multiforme: a meta-analysis of the literature. Int $J$ Mol Sci. 2015;16(5):10443-56. https://doi.org/10.3390/ ijms160510443.

3. Kedrzycki MS, Leiloglou M, Chalau V, Chiarini N, Thiruchelvam PTR, Hadjiminas DJ, et al. The impact of temporal variation in indocyanine green administration on tumor identification during fluorescence guided breast surgery. Ann Surg Oncol. 2021. http s://doi.org/10.1245/s10434-021-10503-2.

4. Pop CF, Barbieux R, Moreau M, Noterman D, Neubourg FD, Chintinne $\mathrm{M}$, et al. Tumor localization and surgical margins identification in breast cancer using ICG-fluorescence imaging. Eur J Surg Oncol. 2019;45(2):e101. https://doi.org/10.1016/j.ejso. 2018.10.352.

5. Veys I, Pop C, Barbieux R, Moreau M, Noterman D, Neubourg FD, et al. ICG fluorescence imaging as a new tool for optimization of pathological evaluation in breast cancer tumors after neoadjuvant chemotherapy. PLoS ONE. 2018;13(5):e0197857. https://doi. org/10.1371/journal.pone.0197857.

Publisher's Note Springer Nature remains neutral with regard to jurisdictional claims in published maps and institutional affiliations. 